\title{
Correspondence
}

The Editor, Foumal of Glaciology

SIR,

\section{Rapid advance of Pumarikish Glacier, Hispar Glacier Basin, Karakoram Himalaya}

Pumarikish Glacier is approximately $7 \mathrm{~km}$ long and flows south from the main crest of the Karakoram. It is one of the main transverse tributaries feeding into the northern margin of Hispar Glacier, which is $62 \mathrm{~km}$ long and flows west from Hispar Pass $(5150 \mathrm{~m})$ and eventually drains into the Hunza River (Fig. 1). Hispar Glacier flows roughly parallel to the southern contact of the Karakoram granite batholith, which corresponds to a belt of mountains with the highest average elevation and the fastest uplift-erosion rates anywhere in Asia (Searle, 1991). Pumarikish Glacier is fed predominantly by avalanches, which originate from the north faces of Pumarikish $(7429 \mathrm{~m})$ and Khinyang Chhish $(7854 \mathrm{~m})$ on the northern and western edges of the basin, and from the lower unnamed peaks of the eastern margin. The granite headwall of Pumarikish Glacier is over $2500 \mathrm{~m}$ from the summit icefields to the upper glacial cirque. The avalanches deposit snow, ice and debris in a small gently sloping basin at $4600-4700 \mathrm{~m}$. The lower $4 \mathrm{~km}$ of Pumarikish Glacier descend gradually from this small accumulation basin to $4000 \mathrm{~m}$ in a well-defined trough less than $500 \mathrm{~m}$ wide.

Recorded observations of Pumarikish Glacier are few. Conway traversed and surveyed Hispar Glacier in 1892.

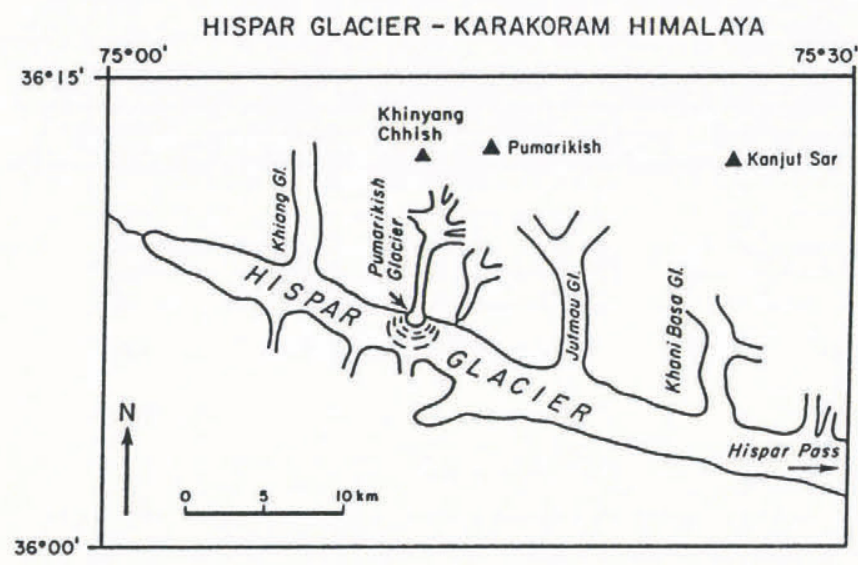

Fig. 1. Location map showing Pumarikish Glacier flowing into the northern margin of Hispar Glacier. The arrow identifies the location of photographs shown in Figure 2.
From observations of tributaries on the north side of Hispar Glacier, Conway (1894) noted that:

"It is remarkable that whereas the Lak Glacier [Khiang Glacier on our map - Figure 1] has so greatly shrunk of later years, this Chur Glacier [Pumarikish Glacier on our map], its immediate neighbor, and which drains another flank of the selfsame mountains, should, on the contrary, have greatly swollen. It overflows all its moraines and pours in a broken spreading wave on to the surface of the Hispar."

Hayden (1907) made no mention of the north-bank tributaries of Hispar Glacier. Dr Kooncza and Dr Caliati, two surveyors who accompanied the 1908 Workman expedition to Hispar Glacier, found that Pumarikish Glacier was "connected by terraces" to the main body of Hispar Glacier (Workman and Workman, 1910). Their map shows a relatively direct crossing of Pumarikish Glacier at the snout. The map produced by Eric Shipton's Karakoram Expedition of 1939 (Mott, 1950) also shows an apparently straighforward crossing of the snout. No account was mentioned of difficulties encountered while crossing this glacier. No mention was made of Pumarikish Glacier in published reviews by Mason (1930), Hewitt (1969), Mercer (1975) or Mayewski and Jeschke (1979).

Our own observations of the glacier began on 19 August 1985 when it was crossed during a reconnaissance of the Hispar Glacier Basin as part of the Snow and Ice Hydrology Project. At that time, the glacier was easy to cross. There was a well-marked path on both lateral moraines and across the glacier used by shepherds to bring their yaks to summer pastures further up the margin of Hispar Glacier. The surface of the glacier showed only mild undulations and was covered in debris which ranged in size from large boulders to silt and mud. The surface was several tens of metres below the top of the lateral moraines. The appearance of the glacier had changed little when it was crossed on 8 August 1987 en route to Hispar Pass. However, by 29 June 1988, the snout of the glacier had thickened by at least $20 \mathrm{~m}$. The surface was still debris-covered but now also showed large debris-covered hillocks and deep valleys. There was no path or obvious route across the glacier. The eastern margin of the glacier was defined by a vertical ice cliff 15$20 \mathrm{~m}$ high which descended to a narrow defile bordered on the far side by the lateral moraine. Steps had to be cut in the ice and the porters were belayed down this section. The upper surface of the glacier was $\approx 10-20 \mathrm{~m}$ below the top of the lateral moraine (Fig. 2a).

Further observations were made during July and August 1989, when a base camp was established at Bitanmal, $3 \mathrm{~km}$ west of Pumarikish Glacier. The snout of 

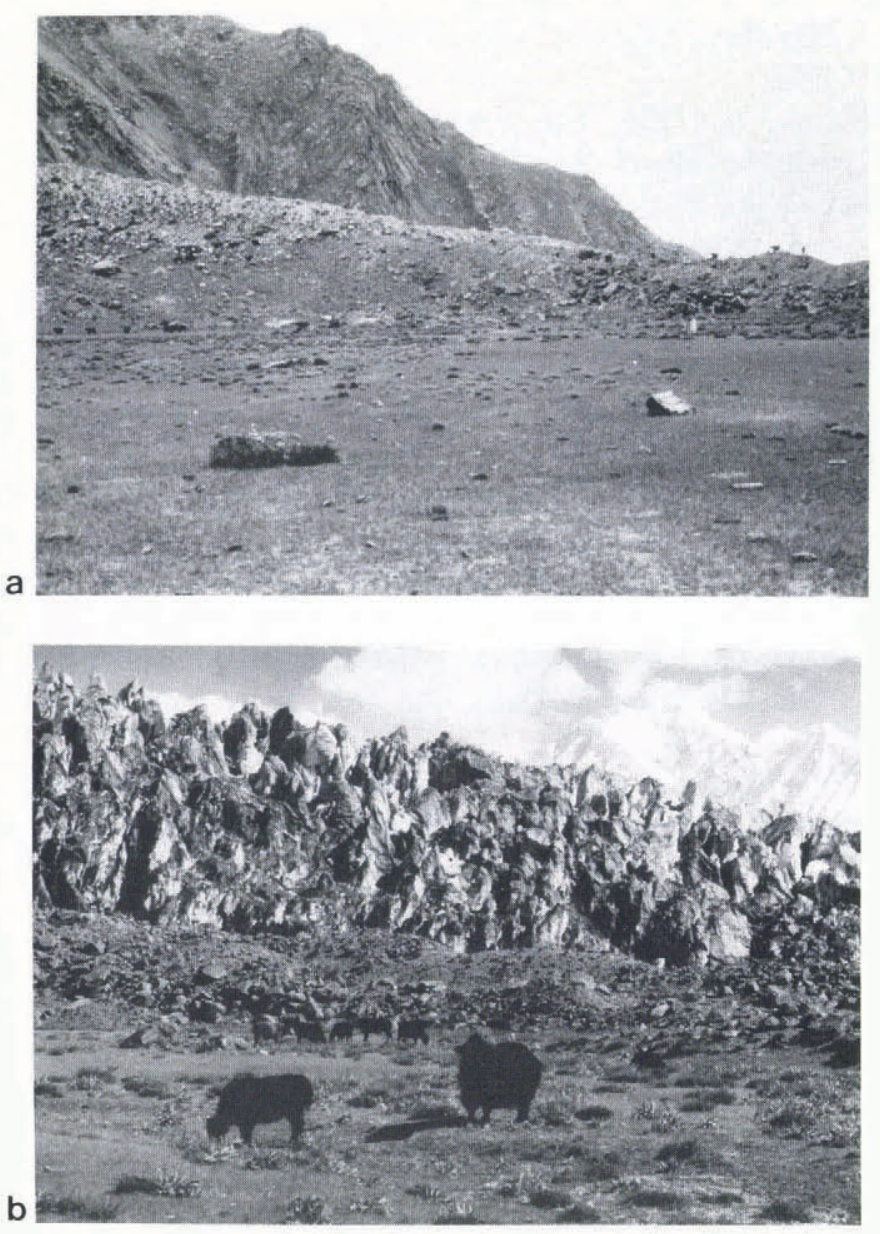

Fig. 2. Photographs of the lateral moraine on the western margin of Pumarikish Glacier looking east from the ablation valley (see arrow in Figure 1). Figure $2 a$ was taken in June 1988 (C. Wake). At this time the glacier was well below the top margin of the lateral moraine and cannot be seen in this photograph. Figure $2 b$ was taken in August 1989 (M. Searle). The glacier was now well above the lateral moraine and showed a heavily crevassed surface.

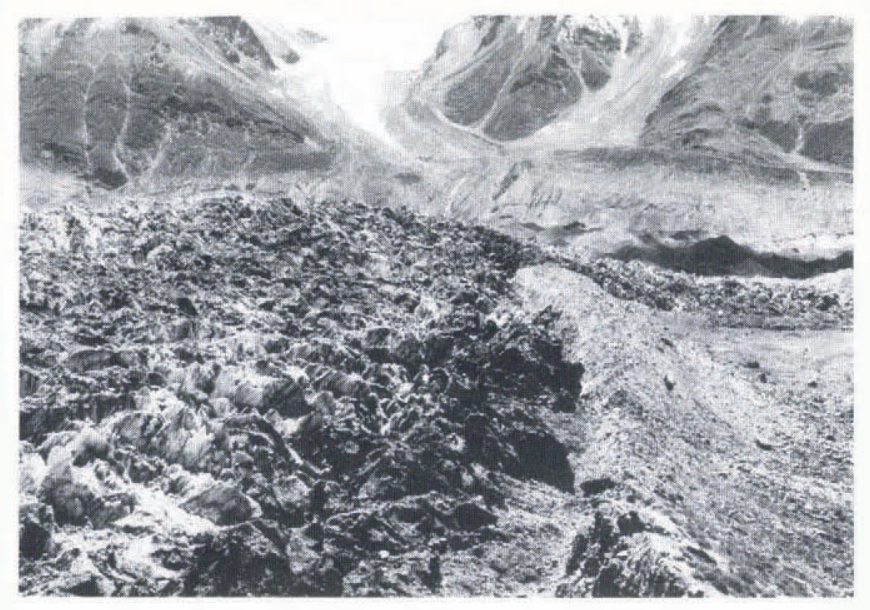

Fig. 3. View looking down the western margin of Pumarikish Glacier. Note that the glacier extends above the lateral moraine (August 1989; M. Searle). The photographs in Figure 2 were taken from the ablation valley on the lower righthand side of this photograph.

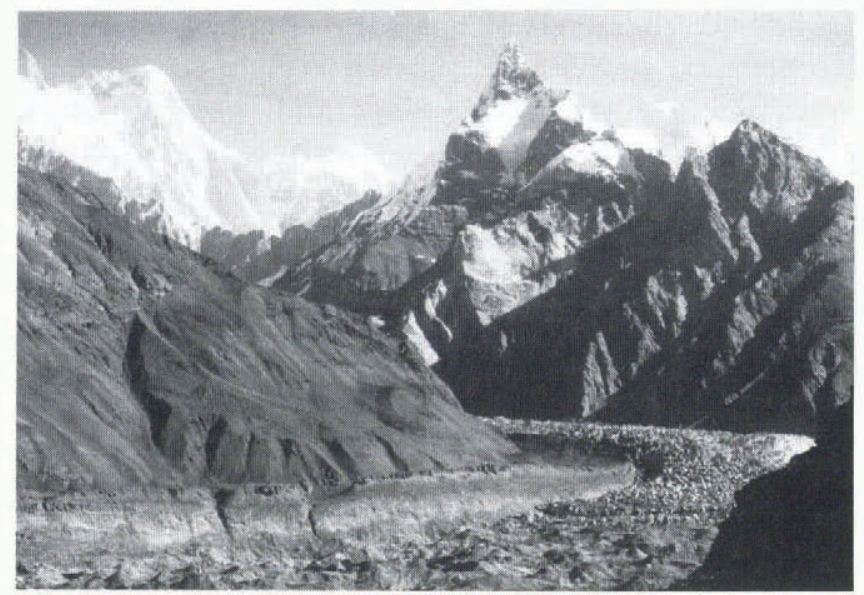

Fig. 4. View north-northeast across Hispar Glacier showing Pumarikish Glacier flowing well out on to Hispar Glacier (August 1989; M. Searle).

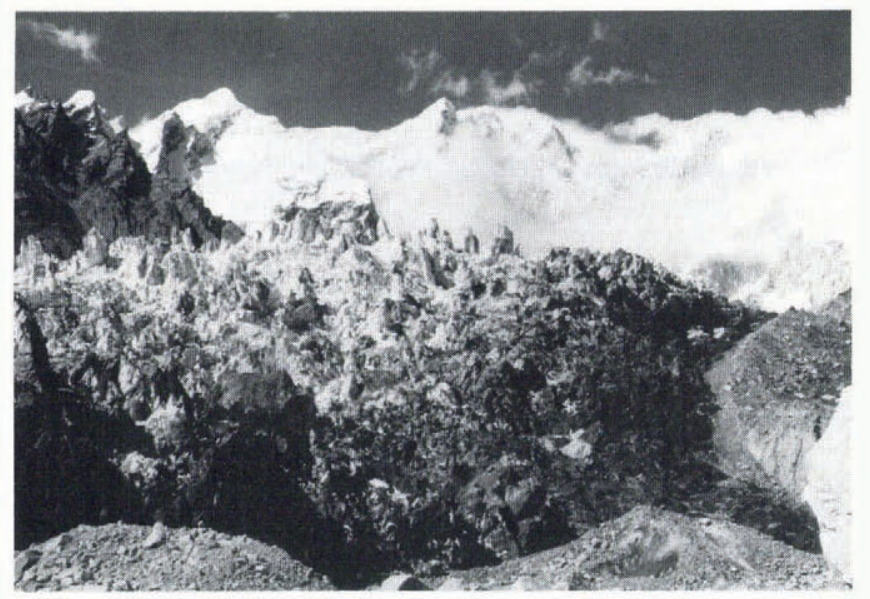

Fig. 5. View of the snout of Pumarikish Glacier from Hispar Glacier (August 1989; M. Searle).
Pumarikish Glacier had thickened so dramatically that the upper surface of the glacier was $16-22 \mathrm{~m}$ above the top of the lateral moraine (Figs $2 \mathrm{~b}$ and 3 ). The glacier had also advanced $1 \mathrm{~km}$, reaching almost the middle of the $2-2.5 \mathrm{~km}$ wide Hispar Glacier (Fig. 4). The entire length of Pumarikish Glacier was now heavily crevassed and impossible to cross at any point (Fig. 5). The regular path up to Hispar Pass was now cut off and to continue up-glacier it was necessary to circumnavigate the advancing snout by travelling out into the middle of Hispar Glacier and around the front of the Pumarikish Glacier ice. This diversion added about $4-6 \mathrm{~h}$ on to the journey. The pastures along the ablation valley beside Hispar Glacier upstream of Pumarikish Glacier were cut off, and the Hispar yaks now grazed mostly at Bitanmal. A brief reconnaissance up Pumarikish Glacier failed to reveal any snow, ice and/or rock deposits which would have been indicative of a major avalanche or landslide. 
It is clear from Conway's observations in 1892 that the upper level of the glacier surface was above the top of the lateral moraines so that ice flowed over them, and that Pumarikish ice flowed well out on to Hispar Glacier. Furthermore, Conway's observation that Khiang Glacier had thinned in the years prior to 1892 indicates that the advance and thickening of Pumarikish Glacier was an isolated event and not characteristic for the north-bank tributaries of Hispar Glacier. The swollen nature of Pumarikish Glacier described by Conway appears strikingly similar to our observations during the summer of 1989, suggesting that the glacier had experienced at least two periods of rapid advance separated by approximately 100 years.

Several glaciers in the Karakoram have been known to surge in the past (Hewitt, 1969; Gardner and Hewitt, 1990). The majority of documented surging glaciers in the Karakoram are concentrated along the main range. In the summer of 1989, Pumarikish Glacier exhibited features characteristic of a glacier in surge: rapid advance of the snout unrelated to activity of nearby glaciers, exceptional rates of advance and the formation of new surface features. In addition, Pumarikish Glacier displays basin-morphology features described by Hewitt (1969) as characteristic of surging glaciers in the Karakoram: medium size for the region, nourishment predominantly via avalanching, and steep tributary glaciers and snow avalanches which supply relatively small, low-angle accumulation zones. While the observational record of Pumarikish Glacier over time is limited, the morphol-ogical changes and repetitive nature of rapid advances over the past century, combined with basin morphology which is characteristic of surging glaciers in this region, suggest that Pumarikish Glacier can be added to the list of documented surging glaciers in the Karakoram.

Glacier Research Group,

Institute for the Study of Earth,

Ocean and Space,

University of New Hampshire,

Durham, New Hampshire 03824, U.S.A.

Department of Earth Sciences,

University of Oxford,

Oxford OX1 3PR, England

MIKE P. SEARLE

CAMERon P. WAKe

20 January 1992 and in revised form 28 February 1992

\section{REFERENCES}

Conway, M. 1894. Climbing and exploration in the Karakoram-Himalaya. New York, Appleton and Co.

Gardner, J. S. and K. Hewitt. 1990. A surge of Bualtar Glacier, Karakoram Range, Pakistan: a possible landslide trigger. F. Glaciol., 36(123), 159-162.

Hayden, H. H. 1907. Notes on certain glaciers in northwest Kashmir. Rec. Geol. Surv. India, 35, 127-137.

Hewitt, K. 1969. Glacier surges in the Karakoram
Himalaya (Central Asia). Can.J. Earth Sci., 6, 10091018.

Mason, K. 1930. The glaciers of the Karakoram and neighbourhood. Rec. Geol Surv. India, 63, 214-278.

Mayewski, P. A. and P. A. Jeschke. 1979. Himalayan and trans-Himalayan glacier fluctuations since A.D. 1812. Arct. Alp. Res., 11(3), 267-287.

Mercer, J.H. 1975. Glaciers of the Karakoram. In Field, W.O., ed. Mountain glaciers of the Northern Hemisphere. Volume 1. Hanover, NH, Cold Regions Research and Engineering Laboratory, 371-409.

Mott, P. G. 1950. Karakoram survey, 1939: a new map. Geogr. F., 116(1-3), 89-95.

Searle, M.P. 1991. Geology and tectonics of the Karakoram Mountains. Chichester, etc., John Wiley and Sons.

Workman, F. B. and W. H. Workman. 1910. The Hispar Glacier. Geogr. J., 35(2), 105-132.

The accuracy of references in the text and in this list is the responsibility of the authors, to whom queries should be addressed. 